\title{
Comparison of yam storage techniques to reduce post Harvest losses with regard to effective storage structures in Ganye local Government Adamawa state - Nigeria
}

\author{
${ }^{1}$ I.G. Adamu, ${ }^{1}$ D.A. Mada, ${ }^{2}$ H.U. Kabri \\ ${ }^{I}$ Adamawa State College of Agriculture, P.M.B 2088, Ganye. Department of agricultural Engineering \\ Technology. \\ ${ }^{2}$ Modibo Adama University of Technology, Yola ,. Department of agricultural and Environmental Engineering.
}

\begin{abstract}
T he objective is to study the effective techniques in reducing the physiological induce post harvest losses in white yam (D.rotundata) in Ganye local Government of Adamawa State - Nigeria. The comparative techniques is to asses weight losses in interval of length of storage using the two method s; wooden box and excavate pit. Fresh sample of yam tubers were weighed and store in both techniques intermittently for duration of 16 weeks. At the end of every month the yam tubers in both methods were weighed and observation recorded. The duration of natural dormancy fluctuates with weight losses between 4 weeks to 16 weeks of storage length. Some of these losses are endogenous i.e. physiological and induced transpiration, respiration and germination. Available information from the experimental result shows that the percentage weight loss of yam tubers stored in wooden box increase to 4 months before sprouting, compare to the pit, which increase to 3 months before sprouting. The loss of fresh yam tuber reduces continuously during length of storage to average of 20 percentage due to ambient temperature and relative humidly during storage. Therefore, yam tubers stored in wooden box prolong the dormancy period for five months before sprouting. Experimental result revealed that yam tubers storage in wooden box is effective than in pit.
\end{abstract}

Keywords: - Yam, storage, techniques, post harvest, losess, storage structures

\section{INTRODUCTION}

Agriculture is a major sector of Nigerian economy. It contributes more than 30 percent of the annual GDP and employs about 70 percent of the labor force more than oil sector. It provides about 80 percent of food stuff needed by the country (Adebaye, 2004). Post harvest loss of yam is 20-30\% from harvest, transportation processing and storage (Mena and Rolle 2002). White yam (D. rotun data) is the most important food crop in West Africa, compare with cereal (Onwueme, 1978). West and central Africa produce about 74 percent of the world yam production (I I TA, 2007)

\subsection{Storage Yam}

Yam is an annual crop; so far it can be available throughout the year. Harvested tubers of yam can be stored for six to eight months without sprouting. The possibility to store fresh yam tubers is their dormancy, which occur short after their physiological maturity (Wilting point). During the dormancy, metabolic functions of the tubers were reduced to a minimum. It allows the tubers as an organ of vegetative propagation to overcome an unfavorable climatic condition. The duration of natural dormancy fluctuates according to the variety of yam from four to eight weeks (Knoth J. 1993).In the storage period, substantial amount of yam is lost. Some of these losses is endogenous i.e. physiological which include; transpiration, respiration and germination. Other losses is caused by exogenous factors such as insects, pest, nematode, rodent and rot bacteria on the stored product (Wilson, J.C 1980)

\subsection{Effective storage structure.}

With regard to effective storage structures and methods evaluated in Edo State, middle belt and Western Nigeria (Osunde,Z.D. and YIsa, M.U. (2000), Adejumo, D .I.(1998). This work showed that the storage structure used depend on the design, construction, material available, amount of tuber produced, prevailing climatic condition of the area, purpose of tuber storage and the resource of the farmers.There are several design and construction of effective structure, but they all consist of a vertical wooden frame work to which tuber are individual attached (Opara,L..U. (1999).Available yam storage structures commonly found in savanna region is yam houses and cribs. Yam houses have thatched roof and wooden floors. (Opara, I.U 1999). They are raised off the ground with rat guard fitted to the pillars. Yam is also stored under ground trench or clamp silos. In underground method, a pit is excavated and lined with straw. The tubers were then stored on the layer of the 
straw with tip vertically downwards, beside each other. Yam tubers are then covered with straw; in some cases a layer of earth is added.

A similar result for sprouting, or germination and weight loss was observed, when intermittent (six hours) air flow was in corporate in conventional barn (Osunde, Z.D , B.A, Orherha (2009)). At the end of the storage period, the percentage of rotting and losses was significantly lower in the barn with intermittent air flow, while the barn without air flow recorded $12 \%$ decayed yam tubers.

\subsection{Prevailing climatic condition of Ganye.}

\section{MATERIALS AND METHODS}

Ganye local Government of Adamawa State - Nigeria is located in Guinea savannah ecological Zone that favors yam production in the world. It is potentially an agricultural area, owning to favorable climatic condition, soil and vegetation (Adebayo, 1999).

\subsection{Procedure of experiment}

The experiment was conducted in Ganye, December 2012 to April 2013. Material used were constructed wooden box, 48 fresh tubers of yam, weighing balance (mp 4800 Delta range,)

Neem leaf ash and excavated pit.

The two methods of storage techniques tested include;

(i) Wooden box method:

A wooden box was constructed with measured dimensions of $35 \mathrm{~cm} \times 25 \mathrm{~cm} \times 25 \mathrm{~cm}$. It was interior lined with neem leaf ash. A total number of 24 yam tubers were weighed to determine initial weight. Tubers were arranged on the lining with touching each other and covered. An open hole is provided on the top of the box to allow ventilation. Intermittently, the tubers will be weighed after 4 weeks to determine loss weight on monthly basis.

\section{(ii) Excavate pit method}

In excavate pit method, 24 yam tubers were also weighed and stored underground in trench. In this method, a pit is excavated $1 \mathrm{mx} 0.5 \mathrm{mx} 1.0 \mathrm{~m}$ dimensions. Lining of neem leaf ash between the tubers were to avoid contact with each other .The 24 yam tubers were stored beside each other and covered with a layer of light soil .

\subsection{Percentage weight loss determination}

The experiment continues intermittent by checking the stored tubers in both methods on monthly basis, for duration of five months. Observations and taking loss weight are recorded as

Shown in table 1and 2. Loss weight is determined by a single instrument $\mathrm{mp} 4800$ delta weighing balance. The subsequent weight lost on monthly basis is subtracted from initial weight of tuber in both methods.

The moisture content influences the physical properties of the yam tubers such as weight and density.

Biological material contains moisture that is the water content per se is seldom of interest as shown in table 3 . The most important control parameter in storage is the moisture. It can be computed by the formula;

Where

$$
\mathrm{Mc}=\frac{M 1-M 2}{M 1}
$$

$$
\begin{aligned}
& M c=\text { moisture loss, } \% \\
& M_{1}=\text { Initial weight of yam sample,kg } \\
& M_{2}=\text { mass of yam sample stored for } 4 \text { weeks---16 weeks,kg. }
\end{aligned}
$$

\section{RESULT AND DISSCUSSION}

The result of this study shows the percentage weight loss of yam tubers stored in wooden box increase with length of storage from 4 weeks to 16 weeks before sprouting. The sprout of yam causes edible tuber material to inedible.

Result of wooden box shows that moisture content reduces continuously during storage length for six months as shown in tables 1-3.

The loss weigth recoded is 20 percent due to transpiration, ambient temperature, relative humidity ,(Osunde,Z.D 2009) reported on the effect of storage condition and storage period on nutritional and other qualities of stored yam (Discorea spp).

In pit storage method, yam tubers sprouts in 3moths to mark the end of dormancy period compare with wooden box, which prolongs the dormancy to 4 months.

The difference in length period of sprouting in experiment is influence by prevailing climatic conditions. White yams (D. rotunda) under normal condition germinate in 20 days at ambient temperature of $25{ }^{\circ} \mathrm{C}$ and relative humidity of 100 percent. 
Plant extracts have been used to improve the quality 0f stored yam tubers (Orhevba, B.A.(2006) The effect of leaf ash treatment on the quality of stored yam tubers was to delayed sprouting period for one month. (Hariprakash, C.S and Nambisan, B. (1996).

This study was carried out to obtain quantitative data as shown in table 1 to 3 on weight loss of stored yam tubers. They were influence by ambient temperature, relative humidity and length of storage (Osunde Z.D (2009), Ezeire, G.O.I (1984). Yam tuber stored for six months in a pit structure with vertical ventilation has low temperature due to shielding from solar radiation and cooling effect of the shaded soil mass surrounding the pit structure. In addition to low temperature in pit, diurnal temperature was also low compare to the barn structures.

Table1. Monthly weight loss of tubers stored in wooden box with initial weight of $35 \mathrm{~kg}$

\begin{tabular}{|l|l|l|l|l|l|}
\hline S/N & Months & $\begin{array}{l}\text { Length of storage } \\
\text { in weeks }\end{array}$ & $\begin{array}{l}\text { Weight recorded at } \\
\text { interval of month kg }\end{array}$ & Weight loss kg & weight loss \\
\hline 1 & Dec. & - & 30.00 & 00.00 & 00.00 \\
\hline 2 & Jan. & 4 & 29.4 & 0.60 & 2.0 \\
\hline 3 & Feb. & 8 & 28.8 & 1.20 & 4.0 \\
\hline 4 & March & 12 & 27.8 & 2.20 & 7.0 \\
\hline 5 & April & 16 & 25.4 & 3.6 & 12.0 \\
\hline 6 & May & 20 & 28.7 & 4.30 & 14.0 \\
\hline
\end{tabular}

Source: Author's file

Table2: Monthly weight loss of tubers stored in pit with initial weight of $27.00 \mathrm{~kg}$

\begin{tabular}{|l|l|l|l|l|l|}
\hline S/N & Months & $\begin{array}{l}\text { Length of storage } \\
\text { in weeks }\end{array}$ & $\begin{array}{l}\text { Weight recorded at } \\
\text { interval of month kg }\end{array}$ & Weight loss kg & weight loss \\
\hline 1 & Dec. & - & 27.0 & 00.0 & 0.00 \\
\hline 2 & Jan. & 4 & 26.8 & 0.2 & 0.7 \\
\hline 3 & Feb. & 8 & 25.4 & 1.60 & 5.992 \\
\hline 4 & March & 12 & 25.0 & 2.0 & 7.41 \\
\hline 5 & April & 16 & 23.4 & 4.6 & 71.0 \\
\hline
\end{tabular}

Source: Author's file

Table3: Comparison of percentage weight loss of two techniques

\begin{tabular}{|l|l|l|l|l|l|}
\hline & Months & $\begin{array}{l}\text { Length of storage } \\
\text { Sks }\end{array}$ & & \% of weight loss & Difference weight loss \\
\cline { 4 - 5 } & & Wooden box & Pit & \\
\hline 2 & Dec & - & 0.00 & 0.00 & \\
\hline 3 & Feb & 4 & 2.0 & 0.7 & \\
\hline 4 & March & 12 & 4.0 & 5.9 & \\
\hline 5 & April & 16 & 7.0 & 7.4 & \\
\hline
\end{tabular}

Source: Author's file

Post harvest engineering perspective of yam storage is the step in enhancing the availability of yam tuber in Ganye market all round the year. It boasts the socio-economic activities of the farmers in the study zone. Engineering principles and design of model structures have been advocated to solve problems of yam storage. It improves the marketing system and farmer's income in the local government area as shown in figure 1to 3

\section{CONCLUTION}

Yam tubers are generally abundant and sold cheaply in the study zone at harvest, but later (especially during the planting season) they become scares and expensive. This technique of wooden box will extend the storage life up to six months. If yam could be stored in wooden box without heavy losses, suppliers could become steadier, price would fluctuate less and farmers would be encouraged to grow their yam by being assured of steadier income. This study has comparative assessment of effective storage structures and treatment with neem leaf ash to improve the quality of stored yam tubers.

However, there is a need for further research in post harvest losses and storage of yam tubers to better understand difference in varietal responses to treatment. Further research should be conducted in the farmer's field with his active cooperation, so that part of the research may be directly linked to his needs and root crop research institutes. 


\section{REFERENCES}

[1] Ganguli, S. (2002). Neem a thera peutic for all season, curr. Sci. June p.1340, 82 (ii)

[2] Geradin, O. Nindjin, C Faraz, Eschet,F. Samp. And Otokore, D. (1998) Effect of storage system and sprout Removal on post harvest yam (Diascorea spp). Fresh weight loss. J. Agric science combridge pp. $130,329,335$.

[3] I I T A (2007) yam research for development.

[4] I I T A publication, Ibrahim, M. H. Williams, J.O. Abidun, M.O (1987) Assessment of parts neem tree for yam tubers storage Rep. Nig. Stored prod. Res. Inst. (4). 37-41.

[5] Knoth, J.(1993).Traditional storage of yam and cassava and its improvement.Deustche Gisellshfat for Technische Zusanment Monenabit (GTZ) Post harvest project. Hamburg, Germany, pp 9-43

[6] Nwanki, A.O. Makurdi, D. (1989) Traditional and some improve method for root and tuber crops in Nigeria. Deutsche stiffing for international Entwicklung (DSE) (ed) Root tubers and legumes, Bonn pp. $51-67$

[7] Opara, L.U. (1999) yam storage in : Bakker Arekema et al (eds). Hand book of Agricultural Engineering. The American society of Agric. Engineering St Joseph M. Agro process iv; 182-214

[8] Osagie, A.U. (1992). The yam tuber in storage, post harvest research unit, university of Benin, Nig. Pp $107-173$

[9] Osunde, Z.D. and Orhevha, B. A.(2009) Effect of storage condition and storage period on nutritional qualities of stored yam (Diacorea spp) tubers AJF ,9 (2) 678 - 690

[10] Osunde, Z.D. and Orhevha, B.A. (2010) Effects of storage conditions and pre-storage treatment on sprouting and weight loss of stored tubers.

[11] Osunde, Z.D.Robertso,G.T. Lupien, J.[2008]Food science and technology to improve nutriention and promote national dadeqiut charpter 12 . Minimizing post harvest losses in yam

[12] Sahore ,D.A.Nemlin, G,K.and Kamenan,A. [2007]. Changes in nutrietional properties of yam [Diascorea s pp] food science technology 47, 81-88

[13] Wickham,J.D [1984]. Dormancy response to post harvest application on growth regulator in [Diascorea spp]. Journal of agricultural science 102, 427-432

[14] Wilson, J.E. [1980]. Careful storage of yam. Common wealth secretariat, London, England, pp2-8.

[15] Hariprakash,C.S. and Nambison, B. [1996] carbohydrate metabolism during dormancy and sprouting in yam [diascorea] tubers; changes in carbohydrate constitutent in yam during dormancy and sprouting. Journal of agricultural and food chemistry 44, 3066-3069

[16] Igberka,J.C.[1985]. Storage practices for yam in Nigeria. Agricultural mechanization in Asia, Africa and lantin America, 16,55-58

[17] Ijabo, O,J. and Jirgba, I.T. [1989] Evaluation of yam storage practices in the middle belt of Nigeria, proceedings of Nigeria society of Agricultural Engineers [NSAE] 13,71-81

[18] Adejumo ,O.I. [1998]. Yam storage structures in western Nigeria .preceeding of the Nigerian society of Agric .engineering [NSAE]conference Bauchi ,Nigeria pp 43-151

[19] Orhevba, B. [2006]. Effect Of pre-storage treatment and storage conditions on some quality of stored yam tubers, unpublished MEng thesis, Federal University of technology, Minna -Nigeria

[20] Ezeike, G.O.I.[1984]. Near optimum condition for yam [D s.pp] tuber storage, preceeding of Nigeria society of Agricultural Engineers [NSAE]conference pp 99-116

[21] 21. Gerardin, D.C.Nindjin, Z. Farah, F, Escher, P.Stamp and D. Otokero (19986) Effect of storage system and sprout removal on post harvest yam (D.SPP) fresh weight loss, Journal of agricultural science.

[22] ..lupien. J.R.[2008] Minimizing post harvest losses in yam [dioscorea ssp]treatment and techniques international union of food science and technology

[23] Olayemi, F.F Adegbola, J.A. Bamishaye, E.I Awagu, E.F. (2013) Assessment of post harvest losses of some selected crops in eight local government area of River state - Nigeria. 
Figure1: weight losses of yam tubers stored in wooden box

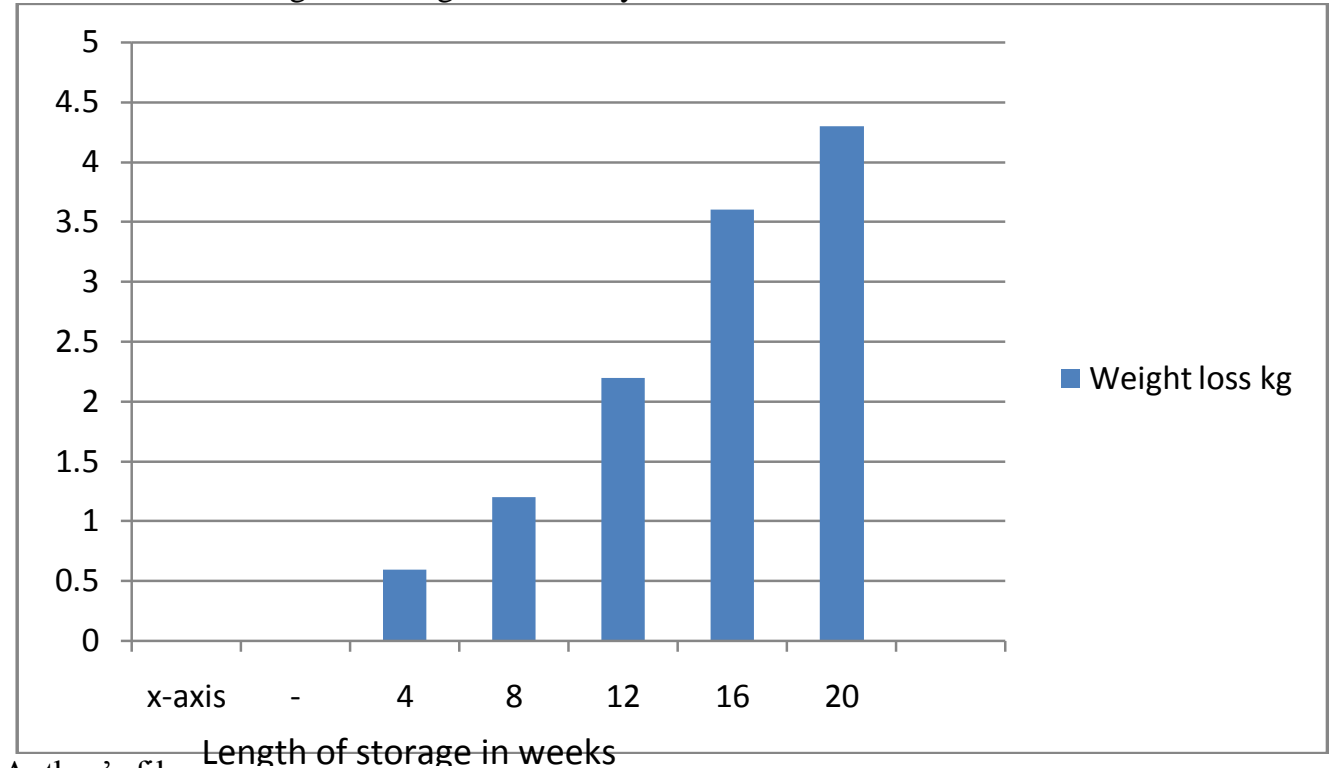

Source: Author's file Length of storage in weeks

Figure2: Weight losses of yam tubers stored in pit

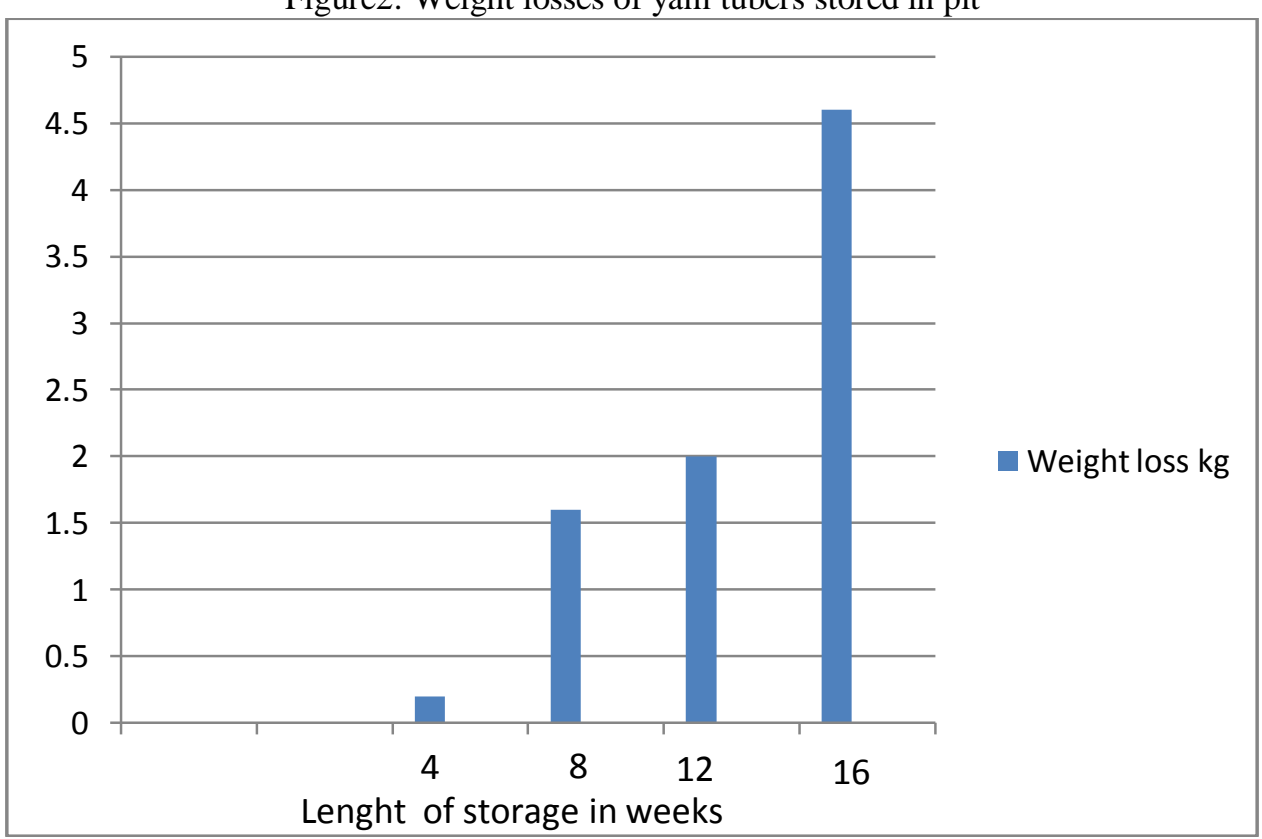

Source: Author's file 
Figure3:Comperison of percentage weight losses of two techniques

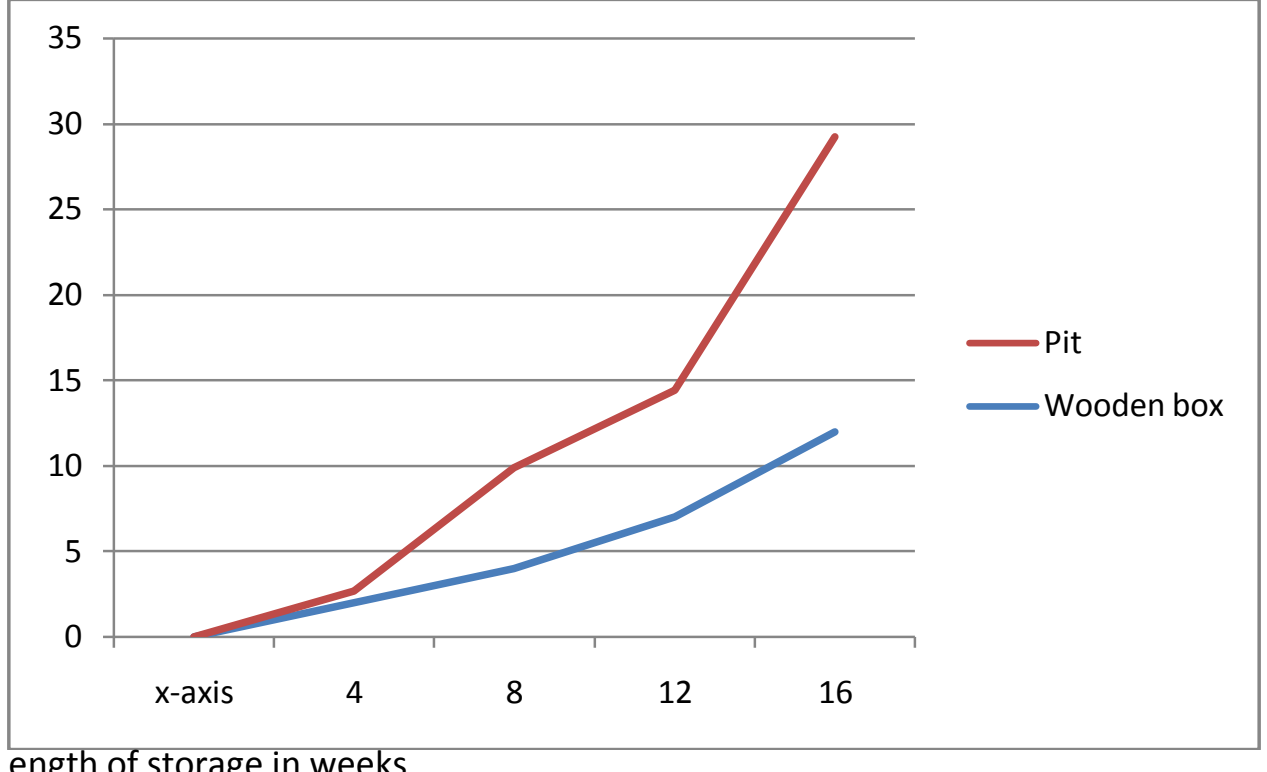

Length of storage in weeks

Source: Author's file 